\title{
Setting Up Sustainable Development of Social Enterprises Model in Indonesia
}

\author{
Natasya Larasati Lontoh ${ }^{1, *}$ Andina Oktariani ${ }^{1}$
}

\author{
${ }^{1}$ School of Business, IPB University, Bogor, Indonesia \\ *Corresponding author. Email: nastasya_larasati@apps.ipb.ac.id
}

\begin{abstract}
Social Enterprise is a business explicitly aimed at social, community, and environment through business structures that can lead to sustainability [5]. In recent years there has been a definite trend towards the development of the social enterprise business model. This phenomenon also occurs in Indonesia. At this time, significant impacts have been felt. Therefore, the existence of social enterprise becomes the principal, helping Indonesia embody the sustainable development. To support social enterprise in Indonesia, this paper conducted a benchmarking on SE in Canada. Canada is a country nominated by the Thomas Foundation 2019 as the first rank for the best country in its social enterprise development. On this study, systematic literature review was applied in order to reach the objectives. This Research has succeeded in identifying several gaps that occur in SE in Indonesia and Canada. Four gaps come from the technology side, business ecosystem, government support. This paper concludes with several recommendation points made to close the gap.
\end{abstract}

Keywords - Business Model, Social Enterprise, Sustainable Development, Systematic Literature Review.

\section{INTRODUCTION}

In recent years, there has been a growth in the formation and recognition of social enterprises as a model for conquering social problems. Therefore, these companies are dedicated to fulfilling missions with fundamentally distinct objectives compared to conventional companies, for example, maximizing profits for owners or shareholders. [1][2]. Currently, SE has taken an essential role as a provider of public services. Moreover, in some cases, they have replaced the state in providing public assistance to citizens [3]. Seeing opportunities and positive impacts on the development of Social Enterprise, some countries and supranational countries have begun to pay attention to SE's existence. The European Union increasingly shew interest to the existence of the SE. This support is manifested in concrete actions. The European Investment Bank (EIB) [4] has prepared a loan of aid funds reported on its website "The European Union, the European Investment Bank (EIB) and the European Investment Fund (EIF) have launched a EUR 200 million loan fund to support lending to micro-enterprises and social enterprises under the EU Programme for Employment and Social Innovation (EaSI)."
The trend of the Social Enterprise phenomenon has cleared away to Indonesia. Based on the results of a survey conducted by the collaboration of the British Council and UNESCAP titled Developing an Inclusive and Creative Economy: The State of Social Enterprise in Indonesia (2018), found the data of the number of SE established per year as below [5].

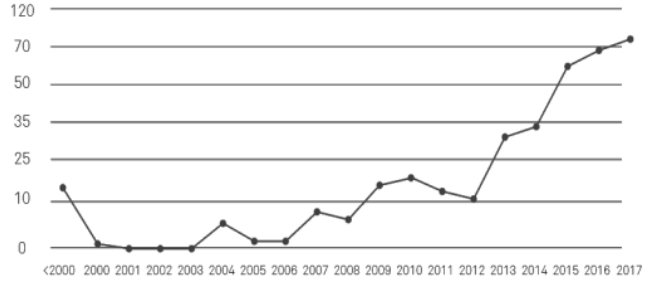

Figure 1 Growth in the number of social enterprises per year

Based on the Figure 1 can be seen an upward trend in the growth of the number of SE in Indonesia. Besides, if further considered, there is a significant growth occurring from 2012 to 2017. Moreover, this survey results estimate the number of SEs in Indonesia to reach 341,025 companies in 2017. 
Social enterprise in Indonesia has shown significant growth in recent years. Its presence has a very positive impact on Indonesia. According to Rhenald Kasali, Professor of the Faculty of Economics and Business, University of Indonesia, reported on the Kontan page (29/04/2014), the existence of sociopreneur is principal. Especially in sectors in a state of crisis, such as education, the environment, agriculture, and health. Furthermore, the presence of sociopreneur can be an extension of the government that is considered unable to solve these problems.

According to [6], social enterprise is a business explicitly aimed at the social, community, and environmental mission through business structures that can lead them to sustainability. At this time, significant impacts have been felt. One of them is increasing employment. Social enterprises in Indonesia can upgrade the total of full-time workers to $42 \%$ and. Moreover, increasing the total of part-time workers to $26 \%$ [5]. For instance, the impact has given the positive change to Indonesia comes from YCAB (Yayasan Cinta Anak Bangsa). The foundation has given a significant number of Indonesian children access to school. YCAB has built 51 Learning Centers, making around 52,650 Indonesian young people continuing education [7]. Another example comes from Kitabisa.com, the largest platform that houses fundraising for various social projects ranging from health financing to disaster relief. This social enterprise, incorporated as a foundation for fundraising activities and a Limited Liability Company (PT) for technology development, has successfully accommodated 16 thousand successfully funded projects. With total funding growth reaching 472 billion in 2018 [8].

Behind the positive trend regarding the growth of the number of SEs in Indonesia, it turns out that at present, the development of SE still faces challenges from various factors. [9]. To be able to answer these challenges, benchmarking is needed to get an overview of best practices. Based on previous research by Thomson Reuters in collaboration with Deutsche Bank CSR, Canada was nominated as the best country for developing a social enterprise [10]. Based on searches through electronic databases (Google Scholar \& Proquest) that have been conducted, no paper discusses the implications of the Canadian social enterprise benchmark for Social Enterprise in Indonesia.

Based on the background and formulation of the problems described previously, the objectives of this study are: (1) Identify social enterprise business models in Canada and Indonesia. (2) Identify gaps between business models in Canada and Indonesia. (3) Setting up recommendations to support the development of a social enterprise business model in Indonesia.

\section{MATERIALS AND METHODS}

\subsection{Material}

Research performed by utilizing literature studies, formal data, and previous Research in several sources of available literature. The data used in the study were obtained through secondary data collection. All data is obtained from several literary sources. The data collected is carried out in a descriptive analysis before being used to answer the research problem formulation.

\subsection{Methods}

This paper uses a qualitative research approach, a method used to answer research problems related to data in the form of narratives that originate from interviews, observations, document extraction [11]. Then the results of the approach have been described in the form of written words.

This study uses a systematic literature review method. This method is implemented to provide a broad overview of the types of social enterprise business models. Besides, this method aims to identify gaps that occur in external factors that have an impact on the existence of SE in Indonesia and Canada.

Scoping Review, Information Sources, and Search Strategy

\section{Eligibility Criteria :}

- Primary Research (can include theses, dissertations, peer-reviewed literature, pre-prints),

- published in English in any year,

- for which the full text was available,

- from any country,

- Concern discussing Social enterprise in Canada or/and Indonesia

Search Process: In searching the literature, researchers used Proquest as a literature source.

Keywords :

- $\quad$ [STRICT] "Social Enterprise*" AND "in Canada*"

- $\quad$ [STRICT] "social enterprise*" AND "Indonesia*"

\section{Inclusion Criteria :}

- Records focus on social enterprise, not investigating social activities, e.g., Charity, CSR.

- Records focus on social enterprise in Indonesia or Canada.

Exclusion Criteria (a) :

- An article does not deal with the concept of business models or the dynamics of development relevant to social enterprises in a given country.

- An article does not deal with the concept of a business model as a construct centered on social enterprises or dynamics directly related to the ability of social businesses to carry out their operations.

Exclusion Criteria (b) : 
- An article does not deal with external conditions (political, social \& cultural, technological, legal, and environmental) that can affect the existence of social businesses in Canada \& Indonesia.

- An article does not deal with how successful social ventures in managing external conditions.

Level 1 Screening-

- Are the title and abstract in English?

- Does the paper meet the Eligibility Assessment?

- Does the paper meet the inclusion criteria?

Level 2 Screening-

- Does not the paper meet the exclusion criteria?

\section{RESULTS}

From the two keywords generated 5021 papers. Within level 1 screening eliminated 3702 papers are not relevant. After level 2 screening, 22 papers were used as research material.

\subsection{Social Enterprise Model in Canada}

Five forms of social enterprise business models have been successfully implemented in Canada [12]. The first form of business model is cooperative. The cooperative business model has been highly developed in this country; there have been six different forms. There is a regulation on the equality of members' democratic law and proportional surplus distribution [13]. Additionally, forms of non-profit organizations in Canada are active. The federal government can give them charity status (which consists of about half of registered nonprofits in Canada). In addition, community-based social enterprise is widely different from cooperatives and non-profit organizations where they can be appropriately articulated in policy, law, or governance at the national level as an organization. The first-nation business model is the fourth form of social enterprise in Canada. A difference between this social enterprise model and the business model described earlier, focusing on the welfare of indigenous peoples as their primary social goals. The last business model is Business with a social mission. This model forms different types of social enterprises, especially in the central and western provinces of Canada. What distinguishes them from the others is that they are traditional businesses that operate for profit. Their supporters argue that they are included to achieve, or focus on, or "installed" to target identifiable social missions, which makes them social enterprises.

\subsection{External Factors Affecting Canadian Social Enterprise}

Geographically, Canada is divided into ten provinces and three regions and five central regions. The existence of social enterprises in Canada was significantly influenced by the diversity of Canadian cultural and legislative contexts [12]. The Canadian government actively participates in providing support for the existence of social enterprises in the country [14][15]. In 2012 the province of Ontario opened a social office in the Ministry of Economic Development, Trade, and Employment. The United States strongly influences the existence of social enterprise in the province of Ontario, and its focus is on entrepreneurship and independenceespecially in the Ontario Anglophone community [16]. Thus the dominant formulation of a social enterprise in Ontario, especially from the perspective of a funding agency, focuses on individual entrepreneurs creating successful businesses.

There are three laws in Canada specifically designed for social enterprises [17]. Nova Scotia passed legislation in 2012 for the Community Interest Company (CIC), following the British policy model. In 2013, Québec passed a law entitled the Social Economy Act (Loi sur leconomie sociale). The purpose of this law was to promote social economics, assist its development with tools, and facilitate access to government programs for economic social enterprises. British Columbia passed a law in 2013 for the Community Contribution Company (CCC), a hybrid company between profit-seeking and non-profit companies.

Acceptance of social enterprises in Canada is motivated by economic developments such as the development of the workforce. This context was based on colonization, including land deprivation; this motivation is behind policies of physical violence, economic deprivation, and social dislocation, specifically imposed on Indigenous women. Factors affecting the development of social enterprises in the context of Indigenous communities in Canada include the ability to convert various types of capital to meet the holistic requirements of various Indigenous communities [18]. In addition, the community's acceptance of Social Enterprise continues due to some historical records. In the 1920s, the Antigonish Movement in the Atlantic of Canada led by Moses Coady and Jimmy Tompkins, motivated by mistrust and anger towards industrial capitalism [13]. Many cooperatives and credit unions were established throughout Atlantic Canada because of this movement. The Antigonish Movement created more than 240 cooperative companies across Atlantic Canada. The cooperative scope extends to several sectors, including fisheries, agriculture, finance (credit unions), housing, and retail (cooperative shops).

The development of SE in Canada is supported by research activites of universities [19]. In addition, with the presence of Curam Software, a provider of software solutions for SE management, it contributes to SE's success in Canada. [20].

\subsection{Social Enterprise Model in Indonesia}


Four main business models dominate Indonesia. The first is a mixed-based model that is used to provide comprehensive solutions to complex problems. Several combinations of activities that are combined innovatively produce a mixed-based business model. This combination makes a comprehensive problem-solving complex. Next is the sharia-based business model. This business model aims to help the poor by providing investment or reducing the shackles of moneylenders from traditional market traders. This business model functions as an independent regulatory organization or a coordinator that increases the coordination of regulatory agencies. The third is the volunteer-based business model. This business model starts from its founder's concern towards problems in the environment around a person, things like waste management, livestock waste, environment, health, and street children. The last is the cooperative business model. This business model has the objectives of improving the economic conditions of its members by developing the local economy. The value upheld in this business model is an increase in the members' income and welfare, as implemented by the Mina Village Cooperation.

\subsection{External Factors Affecting Indonesian Social Enterprise}

Since a long time ago, there have been several efforts to improve welfare. Due to colonialism, Indonesia has experienced a transition from dictatorship to democracy, resulting in the development of national culture and legal framework to reject business competition due to economic control in the hands of the Dutch colonial occupation in the past [21]. Limited business freedom for the native population, encouragement of social organization, and welfare-oriented by the Dutch. On the other hand, there are problems faced by social companies regarding efforts to change paradigms and mindsets [22]. This is a challenge for most leaders in social enterprises because change is not likely to happen instantly. This requires consistent efforts. Therefore, social enterprises generally do not have fast growth instead of focus on gradual and stable change.

The study of Sri Rahayu H H and Idris A [23] shows that there is no significant relationship between extrinsic factors from the community's demographic characteristics (gender, age, marital status, education) to initiatives to support social enterprises. Even religious factors do not have a significant influence on support initiatives. Factors that significantly influence community support are organizational credibility. Economic factors of social enterprises in Indonesia have opportunities from family offices, and wealthy individuals in Asia are intensively making investment impacts that are starting to glance towards social problems [24]. Besides, the international sphere began to support social enterprises in Indonesia. The Canadian
Government and the United Nations Development Program (UNDP) Indonesia agreed to strengthen the role of social finance in Indonesia's funding development actions.

The development of social enterprise in Indonesia is Facebook's number two market outside the US and the third-largest Twitter base. The growth of mobile phones with affordable Internet support has only accelerated the technological boom in a country where 40 million Web users still make up less than 20 percent of the population [25]. Indonesia has several embodiments of social enterprise models, such as limited companies, cooperatives, foundations, and associations. Unfortunately, Indonesia does not yet have a specific identity law called Social Enterprise [21]. Therefore social enterprises in Indonesia tend to compete with other organizations to get public funding. However, social companies in Indonesia continue to work together to achieve their mission to expand their impact on society [22].

\section{DISCUSSION}

\subsection{Identification of Gaps Social Enterprise Governance between Canada and Indonesia}

Based on the results of this study, several gaps occur in the development of social enterprise in Indonesia and Canada. The first gap identified is in terms of technology. The development of social enterprise in Canada has been supported by qualified technology. One example that this Research found was the presence of Steam Software in North America, a provider of Social Enterprise Management (SEM) software solutions. In 2011, Curam Software collaborated with RedMane Technology to develop a commercial off-the-shelf (COTS) solution product [20]. This product is designed specifically for social enterprises and a scalable approach to leverage the solution over time. In contrast, this research has not found a similar technology that can be an external factor supporting Indonesia's social enterprise.

The second gap that has been identified in this research is in terms of creating positive and collaborative business ecosystems for developing social enterprise. In Canada, there is a pioneering community of future cooperation for Canadian social enterprise called Accelerate $\mathrm{AB}$ [26]. The existence of this pioneering community is a pool that accommodates social enterprises to develop mutual connections. This movement enables future collaborative relationships for each of the social enterprises in Kanda. Whereas in this Research, there has not been found any literature that discusses the same thing that can be an external factor supporting social enterprise in Indonesia.

The next context that becomes a gap is the support of the host government in SE funding assistance. 
The Canadian federation government has contributed in providing funds for the development of SE in the country. The literature containing aid activities from the Canadian federation government was published from 2013 until the latest was in 2019 [14][15]. In comparison, this research has not found any literature that includes assistance in providing investment funds to Indonesian social enterprises prepared by the host government.

The last gap that has been identified is government support in terms of regulations and laws for the existing SE business model. In Canada, basic rules and regulations are governing social enterprises under each provincial government. There are at least three regulations specifically designed for social enterprise in Canada [17]. This is part of government support for developing a variety of social enterprise business models in each province of Canada.

\section{CONCLUSION}

In this study concluded that there are four significant gaps between social enterprise in Indonesia and Canada. Contributing to the development of social enterprise in Indonesia, this Research compiles recommendations based on the identification of gaps that occur between Indonesia and countries that are subjected to benchmarking. There is a record of recommendations in several fields, the first being technology. The acquisition of technology to support the improvement of social enterprise work in Indonesia is one of the critical things. Therefore, the government is expected to work with multinational companies, providers of technology supporting social enterprise management, such as steep software. Second, the formation of a positive and collaborative social enterprise ecosystem. This can be applied with the establishment of a similar community Accelerate $\mathrm{AB}$ found in Canada. Next is the role of the government in terms of SE funding assistance in Indonesia. At present international organizations and governments of other countries have been interested in funding development actions in Indonesia. This can be used as a driving wheel of the Indonesian government in supporting the development of SE in Indonesia. The final recommendation comes from the regulations and laws governing SE in Indonesia. Some obstacles experienced by $\mathrm{SE}$ in Indonesia are motivated by the absence of regulations and laws governing the SE environment. Examples such as Indonesian social enterprises that are registered as "foundations", are therefore inherently low in autonomy; and have minimal market legitimacy [27]. At the same time, organizational credibility has a direct influence and positive influence on SI (Support Initiatives). Therefore, the presence of regulations and laws that underlie the SE system in Indonesia is significant.

\section{RESEARCH LIMITATION}

Limitations of this study are based on the literature search phase. This research uses only one source of literature, Proquest. Therefore, this study still needs further research by focusing on the formulation of business models that are suitable to be implemented in Indonesia.

\section{REFERENCES}

[1] J. Defourny, M. Nyssens, Fundamentals for an International Typology of Social Enterprise Models, Voluntas 28(6) (2017) 2469-2497.

[2] E.A.R. Fowler, B.S. Coffey, H. Dixon-Fowler, Transforming Good Intentions into Social Impact: A Case on the Creation and Evolution of a Social Enterprise, Journal of Business Ethics 159(3) (2019) 665-678.

[3] E. Testi, M. Bellucci, S. Franchi, M. Biggeri, Italian Social Enterprises at the Crossroads: Their Role in the Evolution of the Welfare State, Voluntas 28(6) (2017) 2403-2422.

[4] European Investment Bank. 2019 Nov 29, EU Programme for Employment and Social Innovation: EUR 200 million for microfinance institutions and social enterprise lenders across Europe, EIB, 2019.

[5] British Council, Developing an Inclusive and Creative Economy : The State of Social Enterprise in Indonesia, 2018.

[6] M. Bull, H. Crompton, Business Practices in Social Enterprises, Manchester Metropolitan University, 2005. DOI: $10.13140 /$ RG.2.1.3640.5289

[7] YCAB, Impact Report 2018: YCAB Social Enterprise Group, 2018.

[8] Kitabisa, Online Giving Report 2018: Insights for Nonprofits \& Brands, 2018.

[9] Yulius. H. Siregar, N. Tampubolon, The Art of Sustainable Giving, Priorities to accelerate Social Enterprise Growth in Indonesia, 2015.

[10] Thomas Foundation, The best place to be a social entrepreneur. 2019.

[11] Wahidmurni, Pemaparan Metode Penelitian Kualitatif, unpublished, 2017.

[12] J.J. McMurtry, F. Brourard, Social Enterprise in Canada: Context, Models and Institutions, ICSEM Working Papers, No. 04, Liege: The International Comparative Social Enterprise Models (ICSEM) Project, 2015.

[13]D. Lionais, Social Enterprise In Atlantic Canada: Revue Canadienne De Recherche Sur Les OSBL Et L'économie Sociale (ANSERJ) Revue Canadienne 
De Recherche Sur Les OSBL Et L'économie Sociale (ANSERJ), Canadian Journal of Nonprofit and Social Economy Research 6(1) (2015) 25-41.

[14] Federal government lends support for launch of enterprising non-profits canada, enp-canada, a network of social enterprise in communities across the country, (2013, Feb 14), PR Newswire

[15] Canada: Government of canada supports social enterprises led by young people, (2019, Aug 23), Asia News Monitor

[16]F. Brouard, J.J. McMurtry, M. Vieta, Social Enterprise Models In Canada-Ontario: Revue Canadienne De Recherche Sur Les OSBL Et L'économie Sociale (ANSERJ) Revue Canadienne De Recherche Sur Les OSBL Et L'économie Sociale (ANSERJ), Canadian Journal of Nonprofit and Social Economy Research 6(1) (2015) 63-82.

[17] J.J. McMurtry, F. Brouard, Social Enterprises In Canada: An Introduction: Revue Canadienne De Recherche Sur Les OSBL Et L'économie Sociale (ANSERJ) Revue Canadienne De Recherche Sur Les OSBL Et L'économie Sociale (ANSERJ), Canadian Journal of Nonprofit and Social Economy Research 6(1) (2015) 6-24.

[18] U. Sengupta, M. Vieta, J.J. McMurtry, Indigenous Communities And Social Enterprise In Canada: Revue Canadienne De Recherche Sur Les OSBL Et L'économie Sociale (ANSERJ) Revue Canadienne De Recherche Sur Les OSBL Et L'économie Sociale (ANSERJ), Canadian Journal of Nonprofit and Social Economy Research 6(1) (2015) 104-123.

[19] G. MacLeod, B. McFarlane, C.H. Davis, The Knowledge Economy and The Social Economy University Support for Community Enterprise Development as a Strategy for Economic Regeneration in Distressed Regions in Canada and Mexico, International Journal of Social Economics 24(11) (1997) 1302-1324.

[20] Close UP, Curam software reports partnership with RedMane Technology for Social Enterprise Management Opportunities in North America. (2011, Apr 14). Professional Services Close - Up

[21] S. Sengupta, A. Sahay, F. Croce, Conceptualizing Social Entrepreneurship in The Context of Emerging Economies: An Integrative Review of Past Research from BRIICS, International Entrepreneurship and Management Journal 14(4) (2018) 771-803.

[22] R. Rostiani, W. Paramita, H. Audita, R. Virgosita, T. Budiarto, B.R. Purnomo, Understanding Social Enterprises in Indonesia: Drivers and Challenges,
Journal of Indonesian Economy and Business : JIEB 29(2) (2014) 183-191,195-197.

[23]H.H. Sri Rahayu, A. Idris, Antecedents of Customers' Intention to Support Islamic Social Enterprises in Indonesia, Asia Pacific Journal of Marketing and Logistics 26(5) (2014) 707-737.

[24] R. Newell, Seeking an Investment Impact, Asian Investor, 2018, pp. 42-44.

[25]S. Schonhardt, Friendliest Country in Asia for Entrepreneurs? Try Indonesia, The Christian Science Monitor, 2011.

[26] Close UP, Organizers Name Keynote Speakers for Accelerate AB 2016, Professional Services Close Up, 2016.

[27] S. Sengupta, A. Sahay, Social Entrepreneurship Research in Asia-Pacific: Perspectives and Opportunities, Social Enterprise Journal 13(1) (2017) 17-37. 